\title{
Influence of the care of the self in the work of intensive care nurses*
}

\author{
Influência do cuidado de si no trabalho de enfermeiros intensivistas \\ Influencia del cuidado de sí mismo en el trabajo de enfermeros intensivistas
}

How to cite this article:

Silva Júnior EJ, Balsanelli AP, Neves VR. Influence of the care of the self in the work of intensive care nurses. Rev Esc Enferm USP. 2021;55:e03701. doi: https://doi.org/10.1590/S1980-220X2019042403701

\section{Edson José da Silva Júnior ${ }^{1}$ \\ Alexandre Pazetto Balsanelli² \\ Vanessa Ribeiro Neves ${ }^{2}$}

* Extracted from the dissertation: "O cuidado de si do enfermeiro intensivista”, Programa de Pós-Graduação em Enfermagem, Escola Paulista de Enfermagem, Universidade Federal de São Paulo, 2019.

1 Universidade Federal de São Paulo, Escola Paulista de Enfermagem, Programa de Pós-Graduação em Enfermagem, São Paulo, SP, Brazil.

${ }^{2}$ Universidade Federal de São Paulo, Escola Paulista de Enfermagem, Departamento de Administração em Serviços de Saúde e Enfermagem, São Paulo, SP, Brazil.

\begin{abstract}
Objective: To analyze the influence of the care of the self in the work of intensive care nurses. Method: Qualitative study, carried out through thematic oral history. Semistructured interviews were carried out with intensive care nurses who had worked in the area for at least one year and worked in a university hospital located in the south area of the city of São Paulo, Brazil. The script was composed by the guiding question "Does the care of the self affect your professional practice? In what way?". Other questions related to the object of study were added according to the development of each narrative. The speeches were transcribed, transcreated, and analyzed using the Content Analysis Technique. Results: 13 nurses participated in the research. The following categories emerged in their speeches: "Caring for oneself means providing safer care" and "Care of the self and the leadership of intensive care nurses". Conclusion: Practices related to the care of the self, had a positive influence on the work process of the intensive care nurse. This influence was mainly associated with patient safety and leadership development, an important managerial competence.
\end{abstract}

DESCRIPTORS

Critical Care Nursing; Self Care; Occupational Health; Nursing Staff. 


\section{INTRODUCTION}

Intensive Care Units (ICUs) are extremely important for the care of critically ill patients with the possibility of recovery. Everything suggests that the genesis of ICU was on the battlefields of Scutari, Turkey, during the Crimean War (1853-1856), when the nurse Florence Nightingale organized what is now called Modern Nursing ${ }^{(1)}$. This was a milestone in the organization of work and contributed to a significant decrease in the levels of infection among patients and an improvement in the care provided. This was possible due to a strict work organization, which would run uninterrupted 24 hours a day, similarly to a military structure. In addition to scientific, technical, and ethical skills, nurses were required dedication, agility, and a vocation to care for the ill(1) $^{(1)}$.

Although Florence Nightingale received one of the greatest British commendations awarded by Queen Victoria, her dedication also made her ill during the years of the Crimean War. It is known that the nurse contracted typhus and was extremely ill when she was in Scutari ${ }^{(1)}$. This fact confirms what has been described in the literature about nurses: they are professionals who care for other people and constantly forget to take care of themselves ${ }^{(2)}$. It is a paradox that the most significant professional role model of nurses got ill due to their work.

Nurses who work in the ICU have to deal with a complex and stressful work process, with a lot of agitation and stress $^{(3-5)}$. This environment has a great impact on their work and, among other harms, it may pose risks for patient safety ${ }^{(6)}$. The fact that people who care for other people are ill is shocking and causes great impact. However, some strategies described in the literature can allow these professionals to have a better quality of life in their work. Among these strategies, care of the self practices ${ }^{(7)}$ such as reading, writing, philosophy, meditation, reflection and preparation for success, failure or death stand out ${ }^{(8)}$.

An integrative review that analyzed studies on nurses' care of the self between 2006 and 2018 showed that the knowledge of care of the self techniques allows nurses to grow personally and professionally ${ }^{(9)}$. However, no study has analyzed the relationship between care of the self and the work of the intensive care nurse. Thus, the following question is posed: does care of the self influence the work of intensive care nurses? The objective of this study was to analyze the influence of the care of the self on the work of intensive care nurses.

\section{METHOD}

\section{STUDY TYPE}

This is a qualitative, descriptive-exploratory study, which used Thematic Oral History as a research method. This method starts from a specific subject, and the particularities of each narrator only become relevant if aspects that are useful to the central theme are identified. This method is important for the perception of the profession and its interface in society ${ }^{(10)}$.

\section{Population}

Intensive care nurses who worked in the Intensive Care Center (ICC) of a university hospital, located in the South Zone of the city of São Paulo, SP, Brazil, were invited to participate in the study. The referred ICC was composed of two General ICUs and one Neurological ICU, with a total of 35 beds.

\section{SeleCtion CRITERIA}

Nurses specialized in intensive care nursing, with experience of at least one year working in the ICU and availability to participate in the interviews during data collection, which occurred between the months of February and June 2018, were selected. Nurses who were away for vacation or sick leave were excluded.

\section{Data collection}

A total of 13 semi-structured interviews guided by a script with the guiding question "Does care of the self affect your professional practice? In what way?" were conducted. Other questions related to the object of study were added according to the development of each narrative. The interviews were scheduled in person and carried out by the researcher and were conducted in a reserved room close to the ICU, during working hours and according to the availability of nurses. Interviews lasted, on average, 20 minutes and were recorded with a digital device.

\section{Data ANALYSIS AND TREATMENT}

The following steps were followed ${ }^{(11)}$ :

1. Transcription of recordings;

2. Validation of the transcript by the research participants;

3. Transcreation: textualization of the narrative, with the incorporation of the interviewer's questions to the participants' speech and approximation of the texts of narratives that referred to the same theme;

4. Validation of the transcreation by another researcher, who analyzed the correspondence of the text transcreated to the transcript and found no differences between them;

5. Coding and indexing of the topics addressed for the creation of analysis categories, according to the model proposed by Bardin ${ }^{(12)}$. In this stage, 125 Registration Units (RU) were identified and eight codes were established, which originated eight subcategories that were grouped by similarity and thematic relevance in two categories, as shown in Chart 1;

6. Validation of the categories by two other researchers, who analyzed the relevance of the categories to the objectives of the study and to the transcreated text;

7.Interpretation and discussion of thematic categories in the light of the scientific literature on the subject. 
Chart 1 - Coding and grouping of subcategories for the preparation of the categories of this study.

\begin{tabular}{|c|c|c|c|}
\hline $\begin{array}{l}\text { Number } \\
\text { of RU }\end{array}$ & Code & Subcategory & Category \\
\hline 26 & A7 & Patient safety & \multirow{4}{*}{$\begin{array}{l}\text { Caring for oneself } \\
\text { means providing safe } \\
\text { care }\end{array}$} \\
\hline 17 & A17 & Balance & \\
\hline 4 & A35 & Knowledge & \\
\hline 19 & A9 & $\begin{array}{l}\text { Better work } \\
\text { conditions }\end{array}$ & \\
\hline 19 & A8 & Leadership & \multirow{4}{*}{$\begin{array}{l}\text { Care of the self and } \\
\text { the leadership of } \\
\text { intensive care nurses }\end{array}$} \\
\hline 30 & A23 & $\begin{array}{l}\text { Nurse as the role } \\
\text { model }\end{array}$ & \\
\hline 6 & A32 & Resilience & \\
\hline 4 & A36 & Reflection & \\
\hline
\end{tabular}

\section{ETHICAL ASPECTS}

Respecting the rules of Resolution no. 466/12 of the National Health Council, which addresses research involving human beings ${ }^{(13)}$, the project was submitted to the Research Ethics Committee of the Universidade Federal de São Paulo in 2017. The study was approved in the same year under opinion no. 2.342.810. Then, the researcher contacted the ICU nursing management and obtained a list of the names of nurses who met the established selection criteria. Each participant signed an Informed Consent Term, which included the guarantee of anonymity to the interviewees and the use of the testimonies for teaching and research purposes, which dispensed with the elaboration and signature of a copyright assignment letter. To maintain confidentiality of the nurses' identities, the excerpts presented in this study are identified with the letter "E", followed by a number assigned to each participant according to the chronological order in which they were interviewed (E1, E2, E3 ... E13). For the interviews, the name of the first participant was drawn, and this process was repeated throughout the collection period, until the moment when the 13th participant was interviewed, and the data was saturated.

\section{RESULTS}

Thirteen professionals aged between 27 and 48 years old participated in the study. The following categories emerged from their speeches "Caring for oneself means providing safer care" and "Care of the self and the leadership of intensive care nurses".

\section{Care of THE SElF MEANS PROVIDING SAFER CARE}

The self-care practices were described by the participants as a possibility to provide safer care to patients:

I started functional exercises to get stronger and provide better care, because one time a patient had a cardiorespiratory arrest, and I had no breath for chest compression during a resuscitation cycle (E01).

In Nursing, for you to take care of patients and lead the team, you need to take care of yourself, do things that give you pleasure, so you can stay focused with no type of interference (...) When you start paying attention, being more attentive, you can maintain the balance necessary to work in intensive care (E02).

When you take care of yourself, you get balanced and can observe the others and propose more coherent care plans for patients. When you come to work unbalanced, it has a direct impact on your professional practice, and not only for the patient, but for your co-workers as well. You lose your perspective, your focus on the other, because you lost focus on yourself (E03).

When I take care of myself, I take good care of patients, with less stress, less anxiety. I can focus better on what I'm doing. This helps avoiding mistakes (E05).

By taking good care of yourself, you can do a good job. Clinical decision-making, for example, hardly occurs in a hasty manner (E09).

\section{CARE OF THE SELF AND THE LEADERSHIP OF INTENSIVE CARE} NURSES

The interviewees pointed out the benefits that care of the self provides to the exercise of leadership:

By taking care of myself, I can influence other people, being in a good mood, without pain, attending to the team's requests, even giving advice (E01).

The other day I was talking to the technicians, giving my examples, as most of them are very young, and I talked about them taking care of themselves, if they stay in Nursing (E01).

If I am taking care of myself, I will be fine with life, I'll keep a balanced health. So, whatever happens, I will remain firm in the leadership, motivating the staff, encouraging them to provide the best care to the patient. So, care of the self totally influences my work (E04).

The positive influence of the care of the self for problem solving and conflict mediation in the ICU was also mentioned:

Care of the self provides psychological well-being, strengthens self-esteem, helps me to solve problems and conflicts within the team, because I have to be impartial, act professionally, observe all parties and give my opinion on what should be done (E01).

Nurses who take care of themselves and, as a consequence, acquire a degree of emotional stability that allows them to deal with problems within the ICU end up making nursing technicians and assistants confident in performing the tasks and bringing any problems to them (E08).

The speeches revealed that care of the self-strengthens the leader, in different aspects, so they can be seen by the team as role models:

Care of the self influences our work a lot, because we end up being a mirror and, if we remain calm in a stressful environment, in which there are several possibilities of conflict, this can help the team (E08).

In relation to nursing technicians and assistants, I think that us nurses are examples. In a way, our behavior reflects their behavior. If I am a leader who takes care of myself and my posture 
is to exercise, read, seek new knowledge, I believe that this can improve their performance (E06).

If you relate care of the self to reading, studying, acquiring technical knowledge, for example, the consequence of your self-care will be greater knowledge and, by showing this to your technicians, you can influence your team. It ends up having incredibly positive consequences for the team (E08).

\section{DISCUSSION}

One of the most complex environment for nurses' work is the Intensive Care unit ${ }^{(14)}$, where, in addition to caring for critically ill people, nurses need to know how to deal with social and economic demands related to their performance. The ICUs are places marked by work overload and physical and psychological damage to the professionals ${ }^{(15-17)}$. The participants' speeches reveal knowledge about the importance of care of the self to provide safe care to patients and collaborate within the interprofessional team.

Happy and healthy nurses provide greater safety to patients and a healthier work environment ${ }^{(18)}$. The participants in the present study demonstrated that they are aware that taking care of themselves is essential to provide better care for patients. The interviews demonstrated that care for the physical body can provide greater energy to give care. In addition, it was found that mental care strengthens attention and concentration, essential aspects for making correct clinical decisions. This understanding is important so these professionals can act in the promotion and recovery of people's health ${ }^{(14)}$. The professional who has difficulty understanding this reflection and including care of the self practices in their daily habits can act in an improper way in the formulation and implementation of an effective care plan for patients ${ }^{(19)}$.

The speeches of the first category analyzed are similar to a study carried out in Thailand ${ }^{(20)}$ which investigated the effect of burnout on the quality of care provided to patients, on adverse events and on the care outcomes obtained in hospitals in that country. The findings clearly indicate that burnout in nurses is associated with negative results in patient care, and interventions to reduce this condition are essential to improve the care provided.

A parallel can also be made between the results of this study and a study carried out in public hospitals in Portugal, which aimed to explore how nurses' empathy and self-compassion were related to their quality of life $\mathrm{e}^{(21)}$. The results showed that self-compassion and self-care can be important tools to reduce burnout among nurses, increasing their quality of life at work. This can be defined by the perception of potentialities in the work process which can enable workers to achieve happiness, self-fulfillment, well-being, safety, and adequate use of personal energy ${ }^{(22)}$. Thus, care of the self is an extremely important tool for nurses to provide care with less stress, causing fewer errors in people's health care, which is in line with the speeches of the participants in this research.

The results also demonstrated the relationship between care of the self practices and the exercise of leadership. The nurse is the manager of patient care at different levels and, in addition to identifying, planning, and prescribing care, this professional is also responsible for guiding and supervising nursing technicians. However, the complexity of the relationship between nurses and the team members does not make it free from conflicts, which can have positive and negative repercussions on a group of people whose commitment and dedication are necessary to achieve common goals.

Leadership can also be seen as the process of influencing team behavior in order to optimize results and achieve institutional goals. It has been demonstrated that the development of this competence can also improve the quality of the care provided to patients ${ }^{(23)}$. The interviewees demonstrated that self-care provided them with the necessary balance to influence nursing technicians and assistants. This skill strengthens leadership and helps solving important health care challenges, but requires time, dedication and a strong sense of the self to be developed ${ }^{(24)}$. Self-knowledge, described in a study as a consequence of care of the self practices ${ }^{(18)}$, is one of the qualities necessary for leaders to strengthen their influence. Among other things, as described by the participants in this research, self-knowledge can help nurses to reflect on the different ways of managing a wide range of situations ${ }^{(24)}$.

Another relationship between self-care and leadership practices, described in the literature, is related to a characteristic of an authentic leader: self-awareness. A study carried out in the Southeast region of Brazil ${ }^{(25)}$ showed that self-awareness is a valuable tool that includes "confidence in yourself, in your motivations, values, goals, feelings, desires, strengths and weakness, as well as the multifaceted nature of the self". Thus, nurses who reflect on their life and their work process tend to modify their behavior in a positive way, which results in personal and professional growth. This professional will have developed their competence as a leader, a characteristic that certainly reflects positively in their work. They will be able to perceive behavior patterns, limits and potentialities in themselves and in others, because they chose to follow the path of self-knowledge, selfperception, self-awareness, and alertness in life.

Therefore, leadership is an essential competence that needs to be assimilated and developed by nurses, as they are the role model for the nursing team and for other teams that work in healthcare practice, such as the medical team. Their work can be dependent, interdependent, and independent of the work of other professionals. In this sense, they need to have balance, knowledge, confidence, and support for decision making. If they are creative, innovative, and visionary professionals, they can have a positive effect on patients' health outcomes $^{(26)}$. This competence is essential in the ICU, as the severity of the patients' health requires better management of the work team to achieve the best results ${ }^{(27)}$.

The participants'speeches also point to the fact that care of the self practices can make nurses more balanced, aware of their own sensations and in control of their attitudes, which is essential for them to be able to influence their followers. In addition, care practices can improve their posture towards the world. Thus, the nurse will influence the empowerment of the work team.

Practices related to care of the self can create a critical relationship with their work process, considering their 
particular issues and the institutional objectives. Thus, they can develop a greater critical understanding in relation to themselves and others (bosses, colleagues, patients and family members), which will lead to the adoption of healthy habits and give them the energy to provide safer care. In addition, nurses develop the notion that they can and should organize themselves to require health institutions to demonstrate greater concern and commitment to their well-being. Thus, the balance that can be achieved with care of the self practices allows nurses to positively influence their work team.

As a limitation, this study presented the perception of nurses' care of the self in a specific context. Other studies should be carried out in different places and health care settings. However, the research provided advances in knowledge by identifying that care of the self directly influences patient safety through nurse's leadership.

\section{CONCLUSION}

The results of the present study demonstrated that practices related to care of the self have a positive influence on the work process of the intensive care nurse. This influence was mainly associated with patient safety and leadership development, an important managerial competence.

It should be emphasized that the inclusion of topics related to care of the self in the daily lives of professionals by their managers, through continuing education activities, can improve the quality of life of intensive care nurses and bring positive effects to the care provided and to their leadership.

\section{RESUMO}

Objetivo: Analisar a influência do cuidado de si no trabalho de enfermeiros intensivistas. Método: Estudo qualitativo, realizado por meio da História Oral Temática. Foram realizadas entrevistas semiestruturadas com enfermeiros intensivistas que atuavam há pelo menos um ano na área e trabalhavam num hospital universitário localizado na zonal sul do município de São Paulo, Brasil. O roteiro foi composto pela questão norteadora "O cuidado de si interfere na sua prática profissional? De que maneira?". Houve o acréscimo de outros questionamentos pertinentes ao objeto de estudo, de acordo com o desenrolar de cada narrativa. Os depoimentos foram transcritos, transcriados e analisados através da Técnica de Análise de Conteúdo. Resultados: Participaram 13 enfermeiros. Dos discursos, emergiram as categorias "Cuidar de si implica prestar um cuidado mais seguro" e "O cuidado de si e a liderança do enfermeiro intensivista”. Conclusão: As práticas relacionadas ao cuidado de si influenciaram de modo positivo o processo de trabalho do enfermeiro intensivista. Essa influência ocorreu principalmente nos aspectos relacionados à segurança do paciente e ao desenvolvimento da liderança, importante competência gerencial.

\section{DESCRITORES}

Enfermagem de Cuidados Críticos; Autocuidado; Saúde do Trabalhador; Recursos Humanos de Enfermagem.

\section{RESUMEN}

Objetivo: Analizar la influencia del cuidado de sí en el trabajo de enfermeros intensivistas. Método: Se trata de un estudio cualitativo, llevado a cabo mediante la Historia Oral Temática. Se realizaron entrevistas semiestructuradas a enfermeros de cuidados intensivos con al menos un año de antigüedad en el área y que trabajaban en un hospital universitario ubicado en la zona sur de la ciudad de São Paulo, Brasil.El guión estaba compuesto por la pregunta orientadora “¿Interfiere el cuidado de sí en su práctica profesional? ¿En qué sentido?”. Se añadieron otras preguntas pertinentes al objeto del estudio, según el desarrollo de cada relato. Los testimonios se transcribieron, se transcrearon y se analizaron mediante la Técnica de Análisis de Contenido. Resultados: Participaron trece enfermeros. De los discursos surgieron las categorías "Cuidarse a sí mismo implica proporcionar cuidados más seguros" y "Cuidarse a sí mismo y el liderazgo del enfermero de cuidados intensivos". Conclusión: Las prácticas relacionadas con el cuidado de sí mismo han influido de forma positiva en el proceso de trabajo del enfermero intensivista, evidenciándose principalmente en los aspectos relacionados con la seguridad del paciente y el desarrollo del liderazgo, competencia directiva muy importante.

\section{DESCRIPTORES}

Enfermería de Cuidados Críticos; Autocuidado; Salud Laboral; Personal de Enfermería.

\section{REFERENCES}

1. Karimi H, Alavi NM. Florence Nightingale: the mother of nursing. Nurs Midwifery Stud. 2015;4(2):e29475. doi: http://dx.doi.org/10.17795/ nmsjournal29475

2. Blum C. Practicing self-care for nurses: a nursing program initiative. Online J Issues Nurs. 2014;19(3). doi: 10.3912/OJIN.Vol19No03Man03

3. Rushton $\mathrm{CH}$, Batcheller J, Schroeder K, Donohue P. Burnout and resilience among nurses practicing in high-intensity settings. Am J Crit Care. 2015;24(5):412-20. doi:10.4037/ajcc2015291

4. Sargin M, Uluer MS, Cebeci Z, Sargin F. Assessment of depression and quality of life in intensive care unit nurses in a tertiary care hospital. Med Sci. 2018;7(1):101-5. doi: 10.5455/medscience.2017.06.8719

5. Vahedian-Azimi A, Hajiesmaeili M, Kangasniemi M, Fornés-Vives J, Hunsucker RL, Rahimibashar F, et al. Effects of stress on Critical Care Nurses: a national cross-sectional study. J Intensive Care Med. 2019;34(4):311-22. doi: 10.1177/0885066617696853

6. Crane PJ, Ward SE. Self-healing and self-care for nurses. AORN J. 2016;104(5):386-400. doi: 10.1016/j.aorn.2016.09.007

7. Lima EC, Bernardes A, Baldo PL, Maziero VG, Camelo SHH, Balsanelli AP. Critical incidents connected to nurses' leadership in Intensive Care Units. Rev Bras Enferm. 2017;70(5):1018-25. doi: http://dx.doi.org/10.1590/0034-7167-2016-0137

8. White R. Foucault on the care of the self as an ethical project and a spiritual goal. Hum Stud. 2014;37:489-504. doi:10.1007/s10746014-9331-3

9. Silva Junior EJ, Balsanelli AP, Neves VR. Care of the self in the daily living of nurses: an integrative review. Rev Bras Enferm. 2020;73(2):e20180668. doi: https://doi.org/10.1590/0034-7167-2018-0668 
10. Macedo MLAF, Rubim Costa MCMD, Lima SP, Padilha MI, Borenstein MS. Thematic oral history in nursing research: a bibliometric study. Cogitare Enferm. 2014;19(2):360-67. doi: http://dx.doi.org/10.5380/ce.v19i2.37360

11. Neves VR, Sanna MC. Concepts and practices of teaching and exercise of leadership in Nursing. Rev Bras Enferm. 2016;69(3):686-93. doi: http://dx.doi.org/10.1590/0034-7167.2016690417i

12. Bardin L. Análise de conteúdo. Lisboa: Edições 70; 2016.

13. Brasil. Ministério da Saúde. Resolução n ${ }^{\circ}$ 466, de 12 de dezembro de 2012. Dispõe sobre as diretrizes e normas reguladoras das pesquisas envolvendo seres humanos [Internet]. Brasília; 2012 [citado 2019 mar. 2018]. Disponível em: https://bvsms.saude.gov.br/bvs/saudelegis/ cns/2013/res0466_12_12_2012.html

14. Souza MB, Souza NVDO, Tavares KFA, Madriaga LCV. Nursing residents of intensivist scenarios: the importance of selfcare. Rev Enferm UFPE On line. 2017;11(4):1634-40. doi: https://doi.org/10.5205/1981-8963-v11i4a15259p1634-1640-2017

15. Padilha KG, Barbosa RL, Andolhe R, Oliveira EM, Ducci AJ, Bregalda RS, et al. Nursing workload, stress/burnout, satisfaction and incidents in a trauma intensive care units. Texto Contexto Enferm. 2017;26(3):e1720016. doi: http://dx.doi.org/10.1590/0104-07072017001720016

16. Vasconcelos EM, Martino MMF, França SPS. Burnout and depressive symptoms in intensive care nurses: relationship analysis. Rev Bras Enferm. 2018;71(1):135-41. doi: http://dx.doi.org/10.1590/0034-7167-2016-0019

17. Oliveira EM, Barbosa RL, Andolhe R, Eiras FRC, Padilha KG. Nursing practice environment and work satisfaction in critical units. Rev Bras Enferm. 2017;70(1):79-86. doi: http://dx.doi.org/10.1590/0034-7167-2016-0211

18. Crane PJ, Ward SE. Self-healing and self-care for nurses. AORN J. 2016;104(5):386-400. doi: 10.1016/j.aorn.2016.09.007

19. Araujo CB, Costa LMC, Santos RM, Almeida LMWS. The practice of self-care by nursing staff of basic health units. Rev Eletr Enferm. 2016;18:e1181. doi: http://dx.doi.org/10.5216/ree.v18.39304

20. Nantsupawat A, Nantsupawat R, Kunaviktikul W, Turale S, Poghosyan L. Nurse burnout, nurse-reported quality of care, and patient outcomes in Thai Hospitals. J Nurs Scholarsh. 2016;48(1):83-90. doi: 10.1111/jnu.12187

21. Duarte J, Pinto-Gouveia J, Cruz B. Relationships between nurses' empathy, selfcompassion and dimensions of professional quality of life: a cross-sectional study. Int J Nurs Stud. 2016;60:1-11. doi: 10.1016/j.ijnurstu.2016.02.015

22. Hipólito MCV, Masson VA, Monteiro MI, Gutierrez GL. Quality of working life: assessment of intervention studies. Rev Bras Enferm. 2017;70(1):178-86. doi: http://dx.doi.org/10.1590/0034-7167-2015-0069

23. Saleh U, O'Connor T, Al-Subhi H, Alkattan R, Al-Harbi S, Patton D. The impact of nurse managers' leadership styles on ward staff. Br J Nurs. 2018;27(4):197-203. doi: 10.12968/bjon.2018.27.4.197

24. Sherman RO. Leadership influence and power. Nurse Leader, 2018;16(1):6-7. doi: https://doi.org/10.1016/j.mnl.2017.10.003

25. Carvalho AGF, Cunha ICKO, Balsanelli AP, Bernardes A. Authentic leadership and the personal and professional profile of nurses. Acta Paul Enferm. 2016;29(6):618-25. doi: http://dx.doi.org/10.1590/1982-0194201600087

26. Santos JLG, De Pin SB, Guanilo MEE, Balsanelli AP, Erdmann AL, Ross R. Nursing leadership and quality of care in a hospital setting: mixed methods research. Rev Rene. 2018;19:e3289. doi: 10.15253/2175-6783.2018193289

27. Balsanelli AP, Cunha ICKO. Nursing leadership in intensive care units and its relationship to the work environment. Rev Latino Am Enfermagem. 2015;23(1):106-13. doi: 10.1590/0104-1169.0150.2531 